\title{
Determination of physical, mechanical, and structural seed properties of pepper cultivars
}

\author{
Ilknur Alibas ${ }^{1 *}$ and Nezihe Koksal \\ ${ }^{1}$ Department of Biosystems Engineering, Uludag University, 16059 Bursa, Turkey \\ ${ }^{2}$ Department of Horticulture, Cukurova University, Balcali, Adana, Turkey
}

Received May 7, 2014; accepted December 5, 2014

\begin{abstract}
A b s t r a c t. The aim of the present study was to determine various physical, mechanical, and structural characteristics of seed of pepper cultivars Yağlık Kapya, Demre Sivri, Yalova Carliston, Kandil Dolma, and Cin Sus Yediveren, which are grown extensively in Turkey, with initial moisture content ranging between 7.03 and $7.21 \%$ (w.b.). Width, length, and thickness were found to be in the range of 3.00-3.72, 3.43-4.40, and 0.66-0.82 mm, respectively. It was revealed that sphericity of the seeds of Yağlık Kapya, Demre Sivri, Yalova Carliston, Kandil Dolma, and Cin Sus Yediveren were $51,57,56,51$ and $57 \%$, respectively. In terms of the roundness which ranges between 76 and $85 \%$ depending on pepper cultivars. The aspect ratio of Yağl1k Kapya, Demre Sivri, Yalova Carliston, Kandil Dolma, and Cin Sus Yediveren were determined to be $84.60,88.04,94.43,85.55$, and $87.67 \%$, respectively. It was also noted that the porosity of the pepper seeds was in the range of 44.94-49.61\%. Besides, we found that as the weight of pepper seeds increased, their terminal velocity increased accordingly, and thus terminal velocities were found to be $2.87-4.66 \mathrm{~m} \mathrm{~s}^{-1}$. In the current study, the static friction angle and coefficients of the cultivars were determined by means of six different plates including aluminium, stainless steel, galvanized iron, rubber, glass, and plywood. The plywood plate was found to be the least slippery; consequently, the static friction angle and coefficient were determined to be the highest for the plywood plate.

$\mathrm{K}$ e y w o r d s: frictional properties, genetic resources, structural properties, pepper cultivars, physical properties
\end{abstract}

\section{INTRODUCTION}

Peppers (Capsicum spp.), which are commonly grown and used in Turkey as vegetables and spices, belong to the family Solanaceae and provide several essential nutrients (Bae et al., 2012). The antioxidant activity of pepper extracts

*Corresponding author e-mail: ialibas@uludag.edu.tr involves bioactive compounds, such as polyphenols, carotenoids, capsaicinoids, and ascorbic acid (Alvarez-Parrilla et al., 2010; Hervert-Hernandez et al., 2010; Jeong et al., 2011).

Estimation of the genetic diversity of genetic resources and determination of the relationships between germplasm collections may also increase the efficiency of efforts to improve a new species (Bozokalfa et al., 2009; Köksal et al., 2007). However, morphological characterization is the first step in the description and classification of genetic materials. Seeds are vehicles for plant genetic resources, stores of valuable genetic and morphologic information, and expression of biodiversity. Therefore, determination of seed properties is very important for the classification of genetic materials.

Determination of physical and mechanical properties of plant species and cultivars is important to attain successful results in several fields such as plant breeding, packaging, storing (Üçer et al., 2010), engineering, consuming, designing and manufacturing of agricultural machinery such as harvesters, transporter machines, seed drill machines, selecting, sizing, and elevating machines, and food processing such as drying, cooling, and freezing (Abdulah et al., 2011; Alibas and Koksal, 2012; Balasubramanian et al., 2012; Davies, 2010). Seed properties should be considered in breeding studies based on mechanization (Abeels, 1994; Alibas and Koksal, 2012).

In recent years, many researchers have reported physical and mechanical properties of various types of seeds. These include psyllium, lentil, coriander, dragonhead, and hemp seeds (Ahmadi et al., 2012; Bagherpour et al., 2010; Balasubramanian et al., 2012; Dziki et al., 2013; TaheriGaravand et al., 2012, respectively).

(C) 2015 Institute of Agrophysics, Polish Academy of Sciences 
This study investigated some physical, mechanical and structural properties of five pepper cultivars (Yağlik Kapya, Yalova Carliston, Cin Sus Yediveren, Sivri Demre, and Kandil Dolma), which are grown commonly in Turkey; in addition, similarities and differences were identified between these cultivars.

\section{MATERIAL AND METHODS}

For the study of pepper seed properties: Yağlık Kapya, Demre Sivri, Yalova Carliston, Kandil Dolma, and Cin Sus Yediveren cultivars were used. The seeds were produced in Turkey in 2011. The study was conducted in 2012. In order to measure width (W), length (L), and thickness (T), a digital caliper (Mitutoyo, USA) with $0.01 \mathrm{~m}$ sensitivity was used. In order to calculate the geometric mean diameter (D), the three principal dimensions were used as described by Abdullah et al. (2011). The roundness and sphericity values were calculated according to Alibas and Koksal (2012). The aspect ratio (R) and surface area (A) of the seed was calculated according to Avira et al. (1999) and Abdullah et al. (2011).

The angle of repose $(R A)$ was calculated with the equation below (Alibas and Koksal, 2012):

$$
R A=\tan ^{-1}\left(\frac{T_{r}}{r_{r}}\right),
$$

where: $R A$ - angle of repose $\left({ }^{\circ}\right), T_{b}$ - height of repose $(\mathrm{mm})$, $r_{b}$ - mean radius of repose base $(\mathrm{mm})$.

Abdullah et al. (2011) described that the volume for 100 seeds was determined using the water displacement method. In order to prevent water absorption, the seeds were weighed and coated with water resistant glue and allowed to dry. Each seed was lowered into a water-containing measuring cylinder such that the seed did not float during immersion in water. The weight of water relocated by the seed was recorded. The ratio of mass to volume of the seed was calculated as true density. The bulk density is defined as the ratio of the mass of the seed sample to its total volume. According to Yalçın (2007), the bulk density was determined by filling an empty $250 \mathrm{ml}$ cylindrical container with the seeds of the pepper cultivars. The seeds were poured from a constant height, striking off the top level and weighted.

The porosity of the pepper cultivar seeds was calculated from bulk and true densities according to Garnayak et al. (2008) and Üçer et al. (2010).

Aflatbed scanner (Scanjet 3770, Hewlett-Packard Comp. Palo Alto, California) with a resolution of 1200 dpi combined with a special programme (Üçer et al., 2010; Yalçın, 2007) was used to measure the projected area of seeds.

The terminal velocities of seeds were measured using a cylindrical air column (Yalçın, 2007; Üçer et al., 2010). For each experiment, the sample was dropped into the air stream from the top of the air column, up which air was blown to suspend the material in the air stream. The air velocity near the location of the seed suspension was measured by a hot wire anemometer having a least count of $0.01 \mathrm{~m} \mathrm{~s}^{-1}$.
The initial moisture content of the seeds was determined by oven drying at $105 \pm 1^{\circ} \mathrm{C}$ for $24 \mathrm{~h}$ according to Üçer et al. (2010) and Alibas and Koksal (2012).

The mineral matter content was determined according to Alibas and Koksal (2012):

$$
\begin{aligned}
& \% \text { organic }=\frac{H K T-F K T}{F K T} 100, \\
& \% \text { mineral }=100-\% \text { organic },
\end{aligned}
$$

where: $H K T$ - air-dry weight (g), $F K T$ - oven-dry weight (g), \%organic - amount of organic substance within biological material (\%), \%mineral - amount of mineral substance within biological material.

Five grams of the dried products were added to $200 \mathrm{ml}$ distilled water in a $400 \mathrm{ml}$ flask beaker and the samples were kept at $25^{\circ} \mathrm{C}$ for $24 \mathrm{~h}$. After rehydration, the samples were taken out, residual water was removed, and adhering water was absorbed carefully with tissue paper and then weighed (Alibas, 2012). The rehydration capacity $\left(R_{C}\right)$ was calculated as follows:

$$
R_{C}=\frac{W_{r}}{W_{d}},
$$

where: $W_{r}$ is the weight after rehydration $(\mathrm{kg})$ and $W_{d}$ is the weight of dried material $(\mathrm{kg})$.

The germination percentage (GP) was calculated according to Gairola et al. (2011).

In determination of static friction angles of the seeds, we used a system that is sensitive towards slipping and shows the angle where pepper seeds begin to slip with a protractor scale. Static friction angles were measured on 6 different surfaces composed of aluminium, stainless steel, galvanized sheet metal, rubber, glass, and MDF materials (İzli et al., 2009; Alibas and Koksal, 2012). The coefficient of friction was calculated according to İzli et al. (2009).

Data were subjected to ANOVA and means were separated using the LSD test at $p \leq 0.05$. All statistical analyzes were performed using JMP software packages. The study was arranged with three replications and each replication comprised one hundred seeds.

\section{RESULTS AND DISCUSSION}

Some physical, mechanical, and structural properties of five pepper cultivars used in the study are given in Table 1. According to Table 1, the width of Cin Sus Yediveren which is $3.00 \mathrm{~mm}$ significantly lower than that of all the other seed cultivars. Comparison of the differences in length among the cultivars showed that Yağlik Kapya has the highest value of $4.40 \mathrm{~mm}$. The length of Cin Sus Yediveren, which is the smallest cultivar, is by $22 \%$ lower than the length of Yağlık Kapya seeds. No statistically significant difference was found for the thickness of the seeds of the pepper cultivars. Demre Sivri is a cultivar with the 
thickest seeds, $0.82 \mathrm{~mm}$, while Cin Sus Yediveren is characterized by the thinnest seeds $0.66 \mathrm{~mm}$. The results of the measurements of the seed width, length, and thickness are similar to those reported by Üçer et al. (2010). According to Üçer et al. (2010), the length, width, and thickness of red pepper seeds with $7.27 \%$ moisture were found to be 4.46 , 3.66 , and $0.79 \mathrm{~mm}$, respectively.

The length of Yağlık Kapya, Demre Sivri, Yalova Carliston, Kandil Dolma, and Cin Sus Yediveren seeds is greater than their width approximately by $18,13,6,17$, and $14 \%$, respectively. Üçer et al. (2011) found that the length value was higher than the width value by approximately $22 \%$ for red pepper seeds. In the current study, the decrease in the difference between the length and width caused an increase in the aspect ratio, roundness, and sphericity.

The geometric mean diameter of Yağlık Kapya seeds, $2.25 \mathrm{~mm}$, has been found to be the highest. The lowest geometric mean diameter $(1.96 \mathrm{~mm})$ was found for Cin Sus Yediveren pepper seeds; it was by $13 \%$ lower than that of Yağlık Kapya seeds. The geometric mean diameters of six different hybrid corn seeds were found to differ from one another by Babić et al. (2013).

Demre Sivri and Cin Sus Yediveren have the highest sphericity at the rate of $57 \%$. Yağlık Kapya and Kandil Dolma cultivars exhibited the lowest sphericity, by $11 \%$ lower than in cultivars with the highest sphericity. Similar results were also obtained by Üçer et al. (2011), who found the sphericity of red pepper seeds to be 0.525 .

The smallest surface area $\left(12.2 \mathrm{~mm}^{2}\right)$ was found for the Cin Sus Yediveren seeds. On the other hand, the surface area of the Yağlık Kapya seeds, which have the biggest values, was by $32 \%$ larger than that in Cin Sus Yediveren.

Cin Sus Yediveren has the lowest mass of 1000 grains 4.10 g. Yalova Carliston, Kandil Dolma, Demre Sivri, and Yağlık Kapya have 1.33, 1,35, 1,49, and 1.85-fold greater mass of 1000 grains than Cin Sus Yediveren. According to Üçer et al. (2010), the mass of thousand grains of red pepper is $7.97 \mathrm{~g}$. This is by $5 \%$ higher than Yağlik Kapya, which had the highest mass of thousand grains in our study.

Of all the pepper cultivars, Yağlık Kapya has the highest volume $-7.926 \mathrm{~mm}^{3}$, whereas the lowest volume rate was found in Cin Sus Yediveren. The difference between the highest and the lowest volume is approximately $34 \%$.

In terms of true and bulk density, the highest values of 956.52 and $505.11 \mathrm{~kg} \mathrm{~m}^{-3}$ were obtained, respectively, in Yağllk Kapya. True and bulk densities of Cin Sus Yediveren are by 18 and 21\% lower, respectively, than those in Yağlik Kapya. It was determined that the bulk density of Yağlik Kapya, Demre Sivri, Yalova Carliston, Kandil Dolma, and Cin Sus Yediveren were by nearly 89, 92, 82, 82.5, and $98.5 \%$ higher in comparison to their true density.
The decrease in the difference between true and bulk density leads to a decline in porosity; vice versa, porosity increases as the difference between true and bulk increases. In terms of porosity, Cin Sus Yediveren has the highest value at the rate of $49.61 \%$. The porosity of Demre Sivri, Yağlık Kapya, Kandil Dolma, and Yalova Carliston seeds was determined to be by $3.41,4.87,8.95$, and $9.41 \%$ lower, respectively, than that of Cin Sus Yediveren seeds. Cin Sus Yediveren, whose weight and dimensional properties (L, W, T) are the lowest, have the highest porosity, compared to the other pepper cultivars. In our study, the porosity of five different pepper cultivars ranged between 45.17 and $49.61 \%$. According to Üçer et al. (2010), the porosity of red pepper seeds is $49.43 \%$.

In terms of the angle of repose which ranges between 21.09 and $35.45^{\circ}$ depending on pepper cultivars, the difference between the smallest angle (Cin Sus Yediveren) and the biggest angle (Yağlık Kapya) is approximately $40.5 \%$.

Cin Sus Yediveren has the lowest terminal velocity of $2.87 \mathrm{~m} \mathrm{~s}^{-1}$. Furthermore, the terminal velocity of Demre Sivri, Kandil Dolma, Yalova Carliston, and Yağlık Kapya were found to be $1.32,1.36,1.46$, and 1.62 times higher than that of Cin Sus Yediveren, respectively. A relationship was found between the terminal velocity and weight. This means that as the weight increases, the terminal velocity increases. Besides, the terminal velocity of red pepper seeds was found to be $4.36 \mathrm{~m} \mathrm{~s}^{-1}$ by Üçer et al. (2011). On the other hand, in our study, the terminal velocity values of Yağlık Kapya and Demre Sivri were 4.66 and $4.19 \mathrm{~m} \mathrm{~s}^{-1}$, respectively, whereas in such cultivars as Cin Sus Yediveren, which are smaller, the terminal velocity decreased.

Comparison of Cin Sus Yediveren, which has the smallest value, and Yağlik Kapya with the largest value in terms of projected area demonstrated a 33\% difference between the two cultivars. The projected area of chili seeds was $8.40 \mathrm{~mm}^{2}$ as determined by Üçer et al. (2011), whereas, in our study, the projected area of Yağl1k Kapya pepper was found to be $8.31 \mathrm{~mm}^{2}$, which is closer to this value.

The moisture contents of all cultivars have been found between 7.03 and $7.21 \%$; moreover, there was no significant difference among the cultivars in terms of the moisture content. Üçer et al. (2010) found some mechanical and physical properties of red pepper seeds and they estimated the moisture content at $7.27 \%$.

In terms of the mineral matter content, Yağlık Kapya has the highest value of $2.33 \%$. The mineral matter content of Cin Sus Yediveren, which has the lowest value, was 1.13 times lower than that in Yağlık Kapya.

Kandil Dolma was found to have the highest rehydration capacity at the rate of $2.25 \%$. The rehydration capacity rates of Demre Sivri, Yalova Carliston, Cin Sus Yediveren, and Yağlık Kapya are, respectively, 1.22, 1.20, 1.15 and 
T a b l e 1. Seed dimensional and structural properties of pepper (Capsicum annuum) cultivars

\begin{tabular}{|c|c|c|c|c|c|}
\hline \multirow[b]{2}{*}{ Soil properties } & \multicolumn{5}{|c|}{ Cultivars } \\
\hline & Yağlık Kapya & Demre Sivri & Yalova Carliston & Kandil Dolma & $\begin{array}{l}\text { Cin Sus } \\
\text { Yediveren }\end{array}$ \\
\hline Width* (mm) & $3.72 \pm 0.08 \mathrm{a}$ & $3.43 \pm 0.10 \mathrm{a}$ & $3.67 \pm 0.09 \mathrm{a}$ & $3.64 \pm 0.09 \mathrm{a}$ & $3.00 \pm 0.15 b$ \\
\hline Length** (mm) & $4.40 \pm 0.05 \mathrm{a}$ & $3.89 \pm 0.03 \mathrm{c}$ & $3.89 \pm 0.05 \mathrm{c}$ & $4.26 \pm 0.05 b$ & $3.43 \pm 0.02 \mathrm{~d}$ \\
\hline Thickness $^{\mathrm{ns}}(\mathrm{mm})$ & $0.69 \pm 0.05$ & $0.82 \pm 0.07$ & $0.71 \pm 0.02$ & $0.66 \pm 0.04$ & $0.74 \pm 0.02$ \\
\hline $\begin{array}{l}\text { Geometric mean diameter* } \\
(\mathrm{mm})\end{array}$ & $2.25 \pm 0.06 \mathrm{a}$ & $2.22 \pm 0.04 \mathrm{a}$ & $2.16 \pm 0.03 \mathrm{a}$ & $2.17 \pm 0.06 \mathrm{a}$ & $1.96 \pm 0.03 b$ \\
\hline Sphericity* & $0.51 \pm 0.02 b$ & $0.57 \pm 0.01 \mathrm{a}$ & $0.56 \pm 0.01 \mathrm{a}$ & $0.51 \pm 0.02 b$ & $0.57 \pm 0.01 \mathrm{a}$ \\
\hline Roundness $^{\text {ns }}$ & $0.83 \pm 0.01$ & $0.77 \pm 0.04$ & $0.85 \pm 0.01$ & $0.84 \pm 0.01$ & $0.76 \pm 0.03$ \\
\hline Aspect ratio ${ }^{\text {ns }}(\%)$ & $84.60 \pm 1.42$ & $88.04 \pm 2.61$ & $94.43 \pm 2.51$ & $85.55 \pm 3.04$ & $87.67 \pm 4.76$ \\
\hline Surface area* $\left(\mathrm{mm}^{2}\right)$ & $15.90 \pm 0.91 \mathrm{a}$ & $15.48 \pm 0.56 \mathrm{a}$ & $14.72 \pm 0.42 \mathrm{a}$ & $14.83 \pm 0.79 \mathrm{a}$ & $12.12 \pm 0.42 b$ \\
\hline Mass of 1000 seeds $* *(g)$ & $7.58 \pm 0.07 \mathrm{a}$ & $6.10 \pm 0.04 b$ & $5.44 \pm 0.06 \mathrm{c}$ & $5.52 \pm 0.02 \mathrm{c}$ & $4.10 \pm 0.03 \mathrm{~d}$ \\
\hline Volume of 10 seeds $* *\left(\mathrm{~mm}^{3}\right)$ & $79.29 \pm 0.94 \mathrm{a}$ & $63.94 \pm 0.65 b$ & $64.34 \pm 1.10 \mathrm{~b}$ & $63.98 \pm 0.21 b$ & $52.27 \pm 0.72 \mathrm{c}$ \\
\hline True density** $\left(\mathrm{kg} \mathrm{m}^{-3}\right)$ & $956.52 \pm 3.55 \mathrm{a}$ & $953.68 \pm 5.49 \mathrm{a}$ & $845.24 \pm 8.65 b$ & $862.35 \pm 4.74 b$ & $785.24 \pm 8.38 \mathrm{c}$ \\
\hline Bulk density** $\left(\mathrm{kg} \mathrm{m}^{-3}\right)$ & $505.11 \pm 5.75 \mathrm{a}$ & $496.67 \pm 1.67 \mathrm{a}$ & $465.35 \pm 5.11 b$ & $472.73 \pm 4.55 b$ & $395.75 \pm 6.79 \mathrm{c}$ \\
\hline Porosity** (\%) & $47.19 \pm 0.75 b$ & $47.92 \pm 0.19 b$ & $44.94 \pm 0.22 \mathrm{c}$ & $45.17 \pm 0.82 \mathrm{c}$ & $49.61 \pm 0.33 \mathrm{a}$ \\
\hline Angle of repose ${ }^{* *}\left({ }^{\circ}\right)$ & $35.45 \pm 0.90 \mathrm{a}$ & $22.70 \pm 2.12 b$ & $21.55 \pm 0.95 b$ & $21.49 \pm 0.89 b$ & $21.09 \pm 2.23 \mathrm{~b}$ \\
\hline Terminal velocity** $\left(\mathrm{m} \mathrm{s}^{-1}\right)$ & $4.66 \pm 0.08 \mathrm{a}$ & $4.19 \pm 0.09 b$ & $3.80 \pm 0.10 \mathrm{c}$ & $3.89 \pm 0.08 \mathrm{c}$ & $2.87 \pm 0.07 \mathrm{~d}$ \\
\hline Projected area** $\left(\mathrm{mm}^{2}\right)$ & $8.31 \pm 0.03 \mathrm{a}$ & $6.89 \pm 0.09 \mathrm{~d}$ & $7.51 \pm 0.09 \mathrm{c}$ & $8.04 \pm 0.07 b$ & $5.55 \pm 0.05 \mathrm{e}$ \\
\hline $\begin{array}{l}\text { Moisture contentns initial } \\
\text { (\% w.b.) }\end{array}$ & $7.21 \pm 0.03$ & $7.17 \pm 0.02$ & $7.10 \pm 0.04$ & $7.08 \pm 0.05$ & $7.03 \pm 0.08$ \\
\hline Mineral matter content** (\%) & $2.33 \pm 0.05 \mathrm{a}$ & $2.20 \pm 0.03 \mathrm{ab}$ & $2.12 \pm 0.04 b c$ & $2.01 \pm 0.02 \mathrm{~cd}$ & $1.89 \pm 0.11 \mathrm{~d}$ \\
\hline Rehydration capacity** (\%) & $2.00 \pm 0.05 b$ & $1.85 \pm 0.05 \mathrm{c}$ & $1.88 \pm 0.04 b c$ & $2.25 \pm 0.03 \mathrm{a}$ & $1.95 \pm 0.07 \mathrm{bc}$ \\
\hline Germination percentage $^{\text {ns }}(\%)$ & $93.67 \pm 1.20$ & $95.00 \pm 1.73$ & $95.00 \pm 1.15$ & $94.67 \pm 1.45$ & $95.33 \pm 0.88$ \\
\hline $\mathrm{L} / \mathrm{W}^{\mathrm{ns}}$ & $1.18 \pm 0.02$ & $1.14 \pm 0.03$ & $1.06 \pm 0.03$ & $1.17 \pm 0.04$ & $1.15 \pm 0.06$ \\
\hline $\mathrm{L} / \mathrm{T}^{*}$ & $6.40 \pm 0.46 \mathrm{a}$ & $4.79 \pm 0.40 b$ & $5.47 \pm 0.19 \mathrm{ab}$ & $6.49 \pm 0.46 \mathrm{a}$ & $4.65 \pm 0.12 b$ \\
\hline $\mathrm{L} / \mathrm{D}^{*}$ & $1.96 \pm 0.06 \mathrm{a}$ & $1.76 \pm 0.03 b$ & $1.80 \pm 0.04 b$ & $1.96 \pm 0.07 \mathrm{a}$ & $1.75 \pm 0.03 b$ \\
\hline
\end{tabular}

Values in lines followed by the different letters are statistically different at $* \mathrm{p}<0.05, * * \mathrm{p}<0.01$, ns - not significant (LSD).

1.13 times lower than in Kandil Dolma. The germination rates were found to exceed $90 \%$ in all cultivars and no statistically significant difference was found among the cultivars.

The frictional properties of five pepper cultivars used in the study are given in Table 2 and Fig. 1 together with statistical differences. According to Table 2, the static friction angle and coefficient of Yalova Carliston on the aluminium plate (25.17 and $0.47^{\circ}$, respectively) were found to be the lowest of all the cultivars. On the other hand, it was found that Cin Sus Yediveren, which is smallest cultivar, had the highest static friction angle and coefficient $(50.33$ and $1.21^{\circ}$, respectively) on the plywood plate. Comparison of their static friction angles and coefficients showed that the difference between the lowest and the highest value was 2 and 2.57 times, respectively. According to Fig. 1 the static friction angles and coefficients friction on plywood plate were found as the highest value for each of the 


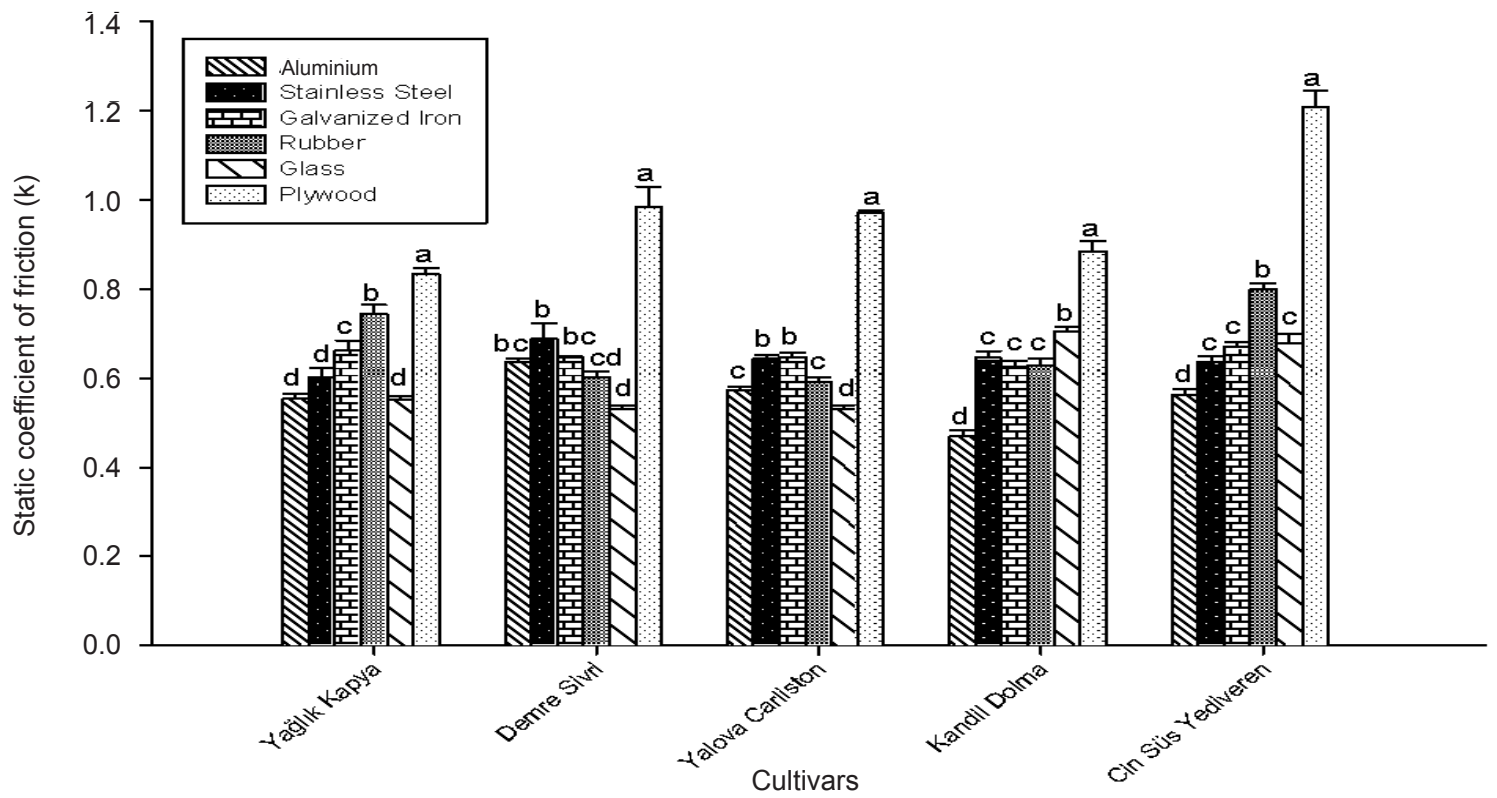

Fig. 1. The static friction coefficient of pepper cultivars depending on the plates used. Values in the group of bars followed by the different letters are statistically different at $*^{*} \mathrm{p}<0.01$ (LSD). LSD has been calculated separately for each of the pepper cultivars.

T a b l e 2. Seed frictional properties of pepper (Capsicum annuum) cultivars

\begin{tabular}{|c|c|c|c|c|c|}
\hline \multirow[b]{2}{*}{ Soil properties } & \multicolumn{5}{|c|}{ Cultivars } \\
\hline & Yağlık Kapya & Demre Sivri & Yalova Carliston & Kandil Dolma & $\begin{array}{l}\text { Cin Sus } \\
\text { Yediveren }\end{array}$ \\
\hline \multicolumn{6}{|c|}{ Static friction angle $\left(^{\circ}\right)$} \\
\hline Aluminium** & $29.00 \pm 0.50 \mathrm{~b}$ & $32.42 \pm 0.36 \mathrm{a}$ & $29.83 \pm 0.30 \mathrm{~b}$ & $25.17 \pm 0.60 \mathrm{c}$ & $29.33 \pm 0.60 b$ \\
\hline Stainless steel ${ }^{\mathrm{ns}}$ & $31.00 \pm 0.87$ & $34.50 \pm 1.38$ & $32.75 \pm 0.38$ & $32.83 \pm 0.60$ & $32.50 \pm 0.50$ \\
\hline Galvanized iron $^{\mathrm{ns}}$ & $33.50 \pm 0.87$ & $32.92 \pm 0.08$ & $32.92 \pm 0.36$ & $32.00 \pm 0.58$ & $33.83 \pm 0.44$ \\
\hline Rubber** & $36.67 \pm 0.73 b$ & $31.08 \pm 0.46 \mathrm{c}$ & $30.58 \pm 0.46 \mathrm{c}$ & $32.17 \pm 0.60 \mathrm{c}$ & $38.67 \pm 0.44 a$ \\
\hline Glass** & $28.83 \pm 0.44 b$ & $28.00 \pm 0.29 b$ & $28.00 \pm 0.29 b$ & $35.17 \pm 0.44 \mathrm{a}$ & $34.17 \pm 0.83 a$ \\
\hline Plywood** & $39.83 \pm 0.44 \mathrm{c}$ & $44.50 \pm 1.32 b$ & $44.17 \pm 0.17 b$ & $41.50 \pm 0.76 \mathrm{c}$ & $50.33 \pm 0.88 \mathrm{a}$ \\
\hline \multicolumn{6}{|c|}{ Static coefficient of friction $(\mathrm{k})$} \\
\hline Aluminium** & $0.554 \pm 0.011 b$ & $0.635 \pm 0.009 a$ & $0.574 \pm 0.007 b$ & $0.470 \pm 0.013 c$ & $0.562 \pm 0.014 b$ \\
\hline Stainless steel ${ }^{\mathrm{ns}}$ & $0.601 \pm 0.021$ & $0.689 \pm 0.036$ & $0.643 \pm 0.009$ & $0.646 \pm 0.015$ & $0.637 \pm 0.012$ \\
\hline Galvanized iron $^{\mathrm{ns}}$ & $0.662 \pm 0.022$ & $0.647 \pm 0.002$ & $0.647 \pm 0.009$ & $0.625 \pm 0.014$ & $0.670 \pm 0.111$ \\
\hline Rubber** & $0.745 \pm 0.020 \mathrm{~b}$ & $0.603 \pm 0.011 \mathrm{c}$ & $0.591 \pm 0.011 \mathrm{c}$ & $0.629 \pm 0.015 \mathrm{c}$ & $0.800 \pm 0.013 \mathrm{a}$ \\
\hline Glass** & $0.551 \pm 0.010 \mathrm{~b}$ & $0.532 \pm 0.007 \mathrm{~b}$ & $0.532 \pm 0.007 b$ & $0.705 \pm 0.012 \mathrm{a}$ & $0.679 \pm 0.021 \mathrm{a}$ \\
\hline Plywood** & $0.834 \pm 0.013 \mathrm{~d}$ & $0.985 \pm 0.045 b$ & $0.971 \pm 0.006 \mathrm{bc}$ & $0.885 \pm 0.024 \mathrm{~cd}$ & $1.207 \pm 0.038 \mathrm{a}$ \\
\hline
\end{tabular}

Explanations as in Table 1. 
pepper cultivars Üçer et al. (2010) determined static friction coefficients of red pepper seeds to be $0.394,0.255,0.298$, and 0.319 using four different rubber, aluminium, stainless steel, and galvanized iron plates.

\section{CONCLUSIONS}

1. The physical, mechanical, and structural properties of five pepper cultivars: Yağlık Kapya, Demre Sivri, Yalova Carliston, Kandil Dolma, and Cin Sus Yediveren were determined. It was found that in terms of seed width and length, Yağlık Kapya exhibited the highest values of 3.72 and $4.40 \mathrm{~mm}$, respectively, whereas Cin Sus Yediveren had the smallest values of 3.00 and $3.43 \mathrm{~mm}$.

2. The highest rates of seed roundness and aspect ratio were found in the Yalova Carliston pepper seeds 85 and $94.43 \%$, respectively. The sphericity of the pepper seeds ranged from 51 to $57 \%$. Moreover, Yağlık Kapya has the highest volume and mass of 1000 seeds. The porosity of pepper seeds ranged from 44.94 to $49.61 \%$, and terminal velocity, which increased with the weight, ranged between 2.87 and $4.66 \mathrm{~m} \mathrm{~s}^{-1}$.

3. The initial moisture and mineral matter contents of the pepper seeds were found to be in the range from 7.03 to $7.21 \%$ and from 1.89 to $2.33 \%$, respectively. The highest moisture content, weight, and the mineral matter content were found in Yağlık Kapya. It was observed that the rehydration capacities and germination rates of pepper seeds ranged between 1.85 and 2.25, 93.67 and $95 \%$, respectively.

4. The static friction angle and coefficient of the pepper cultivar seeds were determined using aluminium, stainless steel, galvanized iron, rubber, glass, and plywood plates; the plywood plate was determined to have the highest angle and coefficient for all cultivars. Besides, it was shown that with its highest static friction angle and coefficient, Cin Sus Yediveren was the smallest cultivar in terms of weight and volume.

5. Results have revealed the importance of the differences among species as well as cultivars while designing and manufacturing machines. In addition, some of the seed parameters could be used in studies in which genetic resources are evaluated.

\section{REFERENCES}

Abdullah M.H.R.O., Ch'ng P.E., and Lim T.H., 2011. Some physical properties of Parkia speciosa seeds. Int. Conf. Food Engineering and Biotechnology IPCBEE, 9, IACSIT Press, Singapoore.

Abeels P.P.F.J., 1994. Mechanization of the planting and plant breeding. Acta Hortic., 355, 85-94.

Ahmadi R., Kalbasi-Ashtari A., and Gharibzahedi S.M.T., 2012. Physical properties of Psyllium seed. Int. Agrophys., 26, 91-93.
Alibas I., 2012. Microwave drying of grapevine (Vitis vinifera L.) leaves and determination of some quality parameters. J. Agric. Sci., 18(1), 43-53.

Alibas I., and Koksal N., 2012. The determination of several physical, gravimetric and frictional seed properties of melon cultivars. Cucurbitaceae Proc. Xth EUCARPIA Meeting on Genetics and Breeding of Cucurbitaceae. October 15-18, Antalya, Turkey.

Alvarez-Parrilla E., de la Rosa L.A., Amarowicz R., and Shahidi F., 2010. Antioxidant activity of fresh and processed jalapeño and serrano peppers. J. Agric. Food Chem., 59, 163-173.

Avira N.A., Gwandzung M.I., and Hague M.A.M., 1999. Physical properties of guna seeds. J. Agric. Eng. Res., 73, 105-111.

Babić L.J., Radojčin M., Pavkov I., Babić M., Turan J., Zoranović M., and Stanišić S., 2013. Physical properties and compression loading behaviour of corn seed. Int. Agrophys., 27, 119-126.

Bae H., Jayaprakasha G.K., Jifon J., and Patil B.S., 2012. Variation of antioxidant activity and the levels of bioactive compounds in lipophilic and hydrophilic extracts from hot pepper (Capsicum spp.) cultivars. Food Chem., 134, 1912-1918.

Bagherpour H., Minaei S., and Khoshtaghaza M.H., 2010. Selected physico-mechanical properties of lentil seed. Int. Agrophys., 24, 81-84.

Balasubramanian S., Singh K.K., and Kumar R., 2012. Physical properties of coriander seeds at different moisture content. Int. Agrophys., 26, 419-422.

Bozokalfa M.K., Eşiyok D., and Turhan K., 2009. Patterns of phenotypic variation in a germplasm collection of pepper (Capsicum annuиm L.) from Turkey. Spanish J. Agric. Res., 7(1), 83-95.

Davies R.M., 2010. Engineering properties of three varieties of melon seeds as potentials for development of melon processing machines. Adv. J. Food Sci. Technol., 2(1), 63-66.

Dziki D., Miś A., Gładyszewska B., Laskowski J., Kwiatkowski S., and Gawlik-Dziki U., 2013. Physicochemical and grinding characteristics of dragonhead seeds. Int. Agrophys., 27, 403-408.

Gairola K.C., Nautiyal A.R., and Dwivedi A.K., 2011. Effect of temperatures and germination media on seed germination of Jatropha curcas L. Adv. Biores., 2(2), 66-71.

Garnayak D.K., Pradhan R.C., Nalk S.N., and Bhatnagar N., 2008. Moisture-dependent physical properties of jatropha seed. Ind. Crops Prod., 27, 127-129.

Hervert-Hernandez D., Sayago-Ayerdi S.G., and Goñi I., 2010. Bioactive compounds of four hot pepper varieties (Capsicum annuum L.), antioxidant capacity, and intestinal bioaccessibility. J. Agric. Food Chem., 58, 3399-3406.

Izli N., Unal H., and Sincik M., 2009. Physical and mechanical properties of rapeseed at different moisture content. Int. Agrophys., 23, 137-145.

Jeong W.Y., Jin J.S., Cho Y.A., Lee J.H., Park S., Jeong S.W., Kim Y.H., Lim C.S., Abd El-Aty A.M., Kim G.S., Lee S.J., Shim J.H., and Shin S.C., 2011. Determination of polyphenols in three Capsicum annuum L. (bell pepper) varieties using high-performance liquid chromatography- 
tandem mass spectrometry. Their contribution to overall antioxidant and anticancer activity. J. Sep. Sci., 34, 2967-2974.

Koksal N., Turhan E., Ipek A., Gulen H., and Eris A., 2007. Clustering of some local common bean (Phaseolus vulgaris L.) genotypes based on carbohydrate metabolism. Proc. Int. Conf. Environment: Survival and Sustainability. February 24-29, Nicosia-Northern Cyprus.
Taheri-Garavand A., Nassiri A., and Gharibzahedi S.M.T., 2012. Physical and mechanical properties of hemp seed. Int. Agrophys., 26, 211-215.

Üçer N., Kılıçkan A., and Yalçın İ., 2010. Effects of moisture content on some physical properties of red pepper (Capsicum annuи L.) seed. Afr. J. Biotechnol., 9(24), 3555-3562.

Yalçın İ., 2007. Physical properties of cowpea (Vigna sinensis L.) seed. J. Food Eng., 79, 57-62. 